\title{
OPEN The behavior of ozone on different iron oxides surface sites in water
}

\author{
Liqiang Yan ${ }^{1}$, Jishuai Bing ${ }^{2} \&$ Hecheng Wu ${ }^{1}$
}

Received: 11 July 2019

A transformation process of ozone on different iron oxides suspensions, including $\alpha-\mathrm{Fe}_{2} \mathrm{O}_{3}, \alpha-\mathrm{FeOOH}$, $\mathrm{Fe}_{3} \mathrm{O}_{4}$, was carried out using FTIR of adsorbed pyridine, ATR-FTIR and electron paramagnetic resonance (EPR) spectra with isotope ${ }^{18} \mathrm{O}_{3}$. It was verified that on the surface isolated hydroxyl groups and the surface hydroxyl groups without acid sites of these iron oxides, ozone was electrostatically adsorbed and did not interact with the surface of these oxides, stably existed as ozone molecule. In contrast, ozone could replace the surface hydroxyl groups on Lewis acid sites of oxides, and directly interacted with the surface metal ions, decomposing into reactive oxygen species (ROS) and initiating the surface metal redox. The results indicate that Lewis acid sites were active center while the electronic cycle of the $\mathrm{Fe}^{2+} / \mathrm{Fe}^{3+}$ is advantageous to promote ozone decomposition into $\mathrm{O}_{2}^{\bullet-}$ and ${ }^{\bullet} \mathrm{OH}$ radicals. The mechanism of catalytic ozonation in different surface acid sites of iron oxides aqueous suspension was proposed on the basis of all experimental information.

Ozone is widely used in the treatment of drinking water and wastewater and the disinfection of artificial pools, etc. ${ }^{1}$. In practical applications, however, the utilization rate of ozone is low and pollutants cannot be completely oxidized, so ozone-based advanced oxidation technology has drawn much attention from researchers ${ }^{2}$. Heterogeneous catalytic ozonation is an effective technology to degrade refractory organic matter and remove residual ozone in ozone treatment water ${ }^{3-5}$. A variety of efficient catalysts have been developed for catalytic ozonation. However, the transformation of ozone on the micro interface of water-catalyst are still largely unknown, which is essential to optimize catalyst development and apply this technique to water treatment ${ }^{6}$.

It has been defined that ozone could be adsorbed on various material surfaces and was decomposed into reactive oxygen species at gas-solid phase ${ }^{7}$. However, John M. Roscoe observed that water molecular has more competitive ability than ozone for the surface of oxides ${ }^{8}$. Therefore, the transformation mechanism of ozone on catalyst suspension becomes more complex due to the presence of a large number of $\mathrm{H}_{2} \mathrm{O}$ molecules ${ }^{6}$. Metal oxides in water are first hydroxylated due to the dissociation and chemical adsorption of water molecules. Surface hydroxyl groups have ligand exchange properties with water, organic pollutants or inorganic ions, and are the main adsorption centers ${ }^{9}$. There are mainly three hydroxyl groups on the surface of oxides: (i) isolated hydroxyl groups; (ii) hydrogen-bonded hydroxyl groups; (iii) bridged hydroxyl groups ${ }^{10-12}$. Different hydroxyls would be formed on different oxides depending on the structure characterization of the oxides, resulting in different catalytic ozonation processes at the water-catalyst interface ${ }^{13}$. Therefore, it is essential to distinguish the different surface reaction process for defining the crucial sites of catalyst surface in catalytic ozonation process.

According to the general viewpoint in the literature of catalytic ozonation, surface hydroxyl and/or Lewis acid sites are considered ozone decomposition sites ${ }^{14,15}$. While other studies have found that not all hydroxyl groups have catalytic activity ${ }^{16}$. Moreover, surface hydroxyl groups were not clarified for the catalytic ozonation. Recently, Our results show that ozone can be adsorbed on the surface of Lewis acid competing with water and decompose to produce reactive oxygen species (ROS) ${ }^{17}$. Nevertheless, to date, it is still not very clear for the transformation of ozone on non-dissociated hydroxyl groups or different acid sites of metal oxides at water-solid phase.

The purpose of this study was to investigate the behavior of ozone on the surface of iron oxides and identify the key surface factors of catalysts that play a key role in ozone conversion. Three kinds of oxides, $\alpha-\mathrm{Fe}_{2} \mathrm{O}_{3}$, $\alpha-\mathrm{FeOOH}$ and $\mathrm{Fe}_{3} \mathrm{O}_{4}$, commonly used in catalytic ozonation were selected. Different iron oxides have different crystal forms and thus have different surface sites. Both the hydroxylation of these iron oxides and the adsorption of ozone were followed by in situ attenuated total reflection infrared (ATR-FTIR) spectroscopy, the competition of ozone and water for different surface sites was verified. Furthermore, the decomposition of ozone was determined

\footnotetext{
${ }^{1}$ Nanjing University of Aeronautics and Astronautics, School of Economics and Management, Nanjing, 210016, China. ${ }^{2}$ Marine Resources Development Institute of Jiangsu, Huaihai Institute of Technology, Lianyungang, 222005, China. Correspondence and requests for materials should be addressed to L.Y. (email: lygylq@126.com) or J.B. (email: jshbing@126.com)
} 


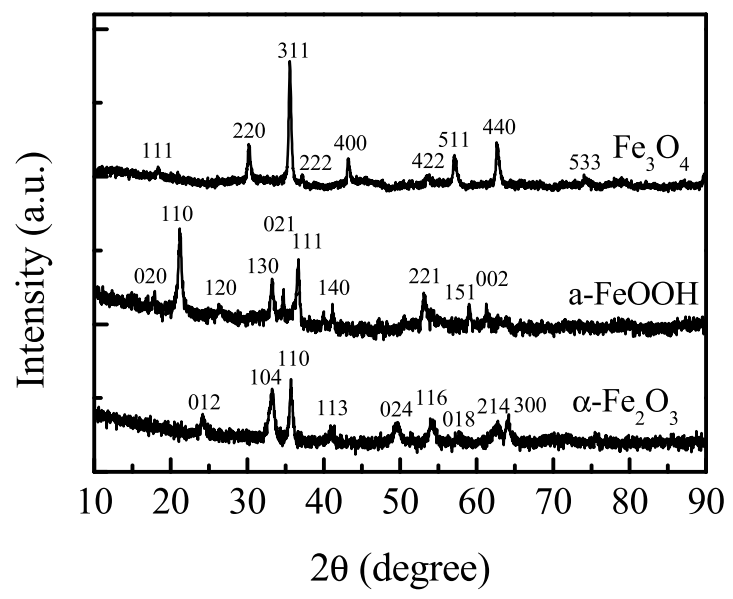

Figure 1. $\mathrm{XRD}$ patterns of $\alpha-\mathrm{Fe}_{2} \mathrm{O}_{3}, \alpha-\mathrm{FeOOH}$ and $\mathrm{Fe}_{3} \mathrm{O}_{4}$.
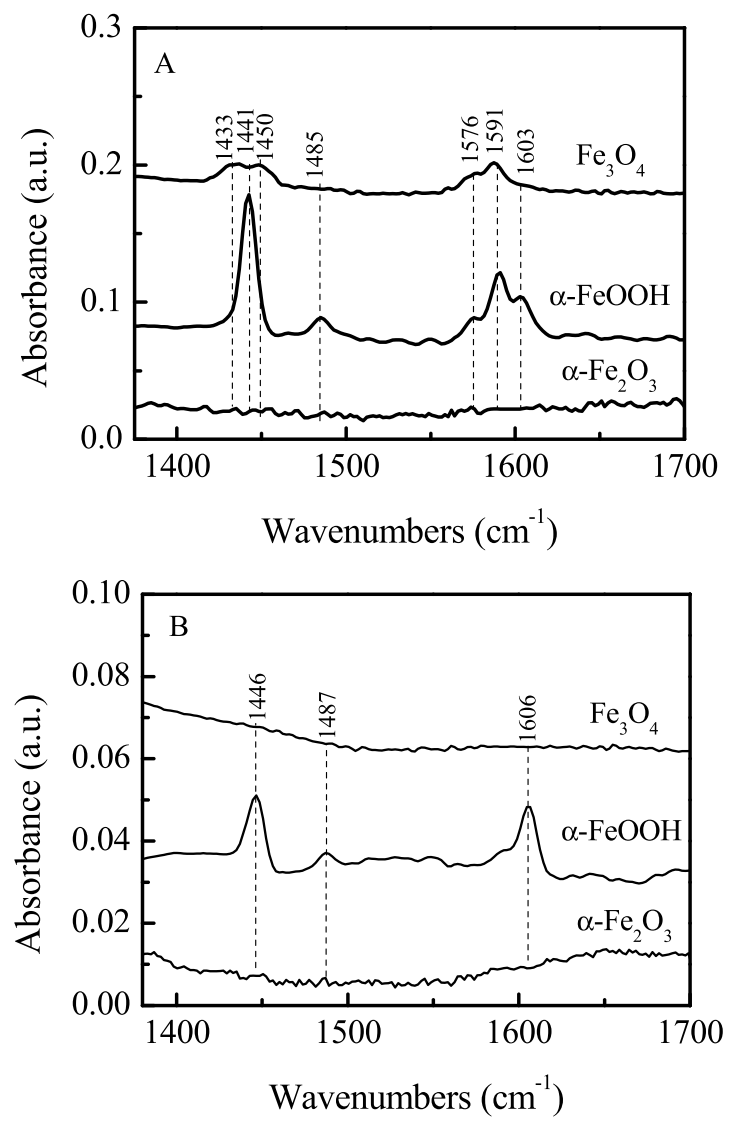

Figure 2. Py-FTIR for $\alpha-\mathrm{Fe}_{2} \mathrm{O}_{3}, \alpha-\mathrm{FeOOH}$ and $\mathrm{Fe}_{3} \mathrm{O}_{4}$ after outgassing at (A) $20^{\circ} \mathrm{C}$ and (B) $150^{\circ} \mathrm{C}$.

by electron paramagnetic resonance (EPR) spectra with oxygen isotope ${ }^{18} \mathrm{O}_{3}$. The activity and properties of these oxides was evaluated by ibuprofen (IBU), which is an anti-inflammatory drug, has been detected in surface water and wastewater at a range from ng to low $\mu \mathrm{g} \mathrm{L}^{-1}$ levels due to its stability for photolysis and biodegradation. The highlight of this paper is to reveal the relationship between the mechanism of catalytic ozonation and the acidity characterization of the catalyst surface, which provides theoretical support for the development of new catalysts.

\section{Results and Discussion}

Characterization of catalysts. The XRD patterns of iron oxides were shown in Fig. 1. All the samples exhibited the typical crystalline structure of $\alpha-\mathrm{Fe}_{2} \mathrm{O}_{3}$ (JSPDS card 01-073-2234), $\alpha-\mathrm{FeOOH}$ (JSPDS card 01-0810463) and $\mathrm{Fe}_{3} \mathrm{O}_{4}$ (JSPDS card 01-088-0315), respectively, and no additional phase was contained in the samples, indicating the iron oxides were successful prepared. The nature and strength of acid sites of iron oxides were 


\begin{tabular}{|l|l|l|l|l|}
\hline & & & \multicolumn{2}{|l|}{ Lewis acid amount $\left(\mathbf{u m o l ~ g}^{-1}\right)$} \\
\cline { 5 - 6 } Sample & $\mathbf{N s}\left(\mathbf{m m o l ~ g}^{-1}\right)$ & $\mathbf{p H}_{\mathbf{p z c}}$ & $\mathbf{2 0}{ }^{\circ} \mathbf{C}$ & $\mathbf{1 5 0}^{\circ} \mathbf{C}$ \\
\hline$\alpha-\mathrm{Fe}_{2} \mathrm{O}_{3}$ & 57 & 7.2 & 0 & 0 \\
\hline$\alpha-\mathrm{FeOOH}$ & 330 & 8.6 & 795.4 & 106.7 \\
\hline $\mathrm{Fe}_{3} \mathrm{O}_{4}$ & 116 & 6.8 & 307.6 & 0 \\
\hline
\end{tabular}

Table 1. Surface area, surface hydroxyl site density (Ns), $\mathrm{pH}_{\mathrm{pzc}}$ and Lewis acid amount degassing at 20 and $150^{\circ} \mathrm{C}$ of $\alpha-\mathrm{Fe}_{2} \mathrm{O}_{3}, \alpha-\mathrm{FeOOH}$ and $\mathrm{Fe}_{3} \mathrm{O}_{4}$.

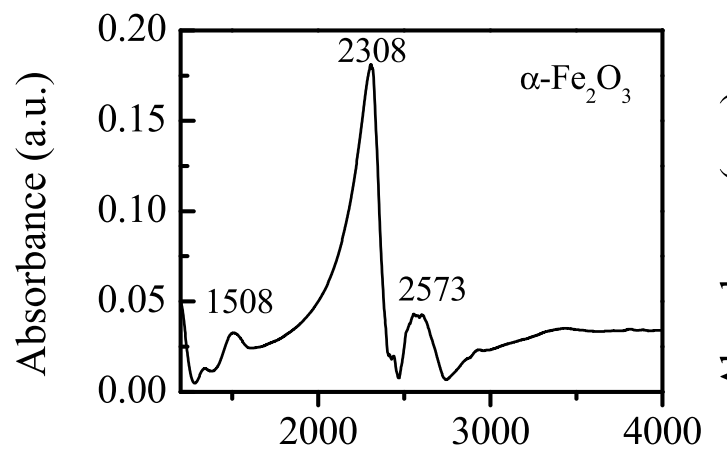

Wavenumbers $\left(\mathrm{cm}^{-1}\right)$

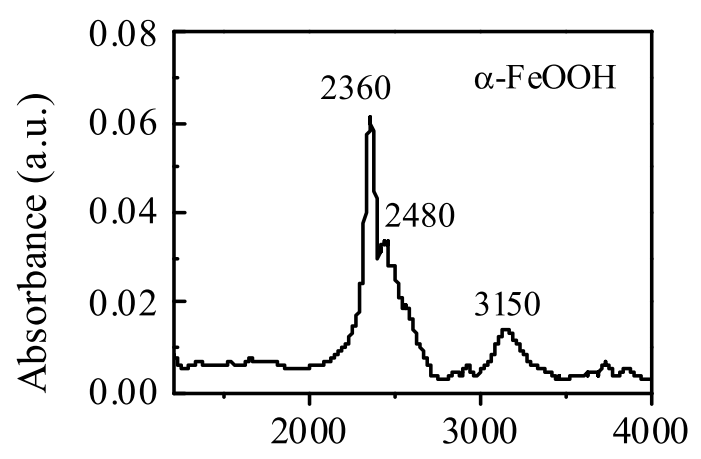

Wavenumbers $\left(\mathrm{cm}^{-1}\right)$

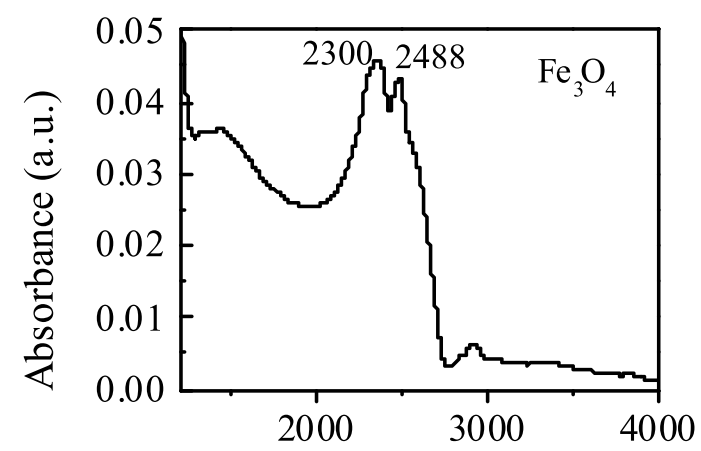

Wavenumbers $\left(\mathrm{cm}^{-1}\right)$

Figure 3. ATR-FTIR spectra of different iron oxide suspensions in $\mathrm{D}_{2} \mathrm{O}$. (Catalyst concentration: $\left.100 \mathrm{gL}^{-1}, \mathrm{pD}: 7.0\right)$.

further determined by Py-FTIR after degassing at $20^{\circ} \mathrm{C}$ and $150^{\circ} \mathrm{C}$ (Fig. 2). In the Py-FTIR spectra, after degassing at $20^{\circ} \mathrm{C}$ and $150^{\circ} \mathrm{C}$, no peak was observed for $\alpha-\mathrm{Fe}_{2} \mathrm{O}_{3}$, indicating that there is no acid sites in $\alpha-\mathrm{Fe}_{2} \mathrm{O}_{3}$. For $\mathrm{Fe}_{3} \mathrm{O}_{4}$ and $\alpha-\mathrm{FeOOH}$, six infrared absorption peaks around 1433, 1441, 1450, 1576, 1591 and $1603 \mathrm{~cm}^{-1}$ of Lewis acid sites appeared in the Py-FTIR spectra after degassing at $20^{\circ} \mathrm{C}$. However, all the IR absorption peaks of $\mathrm{Fe}_{3} \mathrm{O}_{4}$ were entirely removed at $150^{\circ} \mathrm{C}$, indicating these infrared absorption peaks are the adsorption of pyridine on weak Lewis acid sites ${ }^{18,19}$. While in $\alpha-\mathrm{FeOOH}$ sample, the intensity of all infrared absorption peaks becomes weaker and all peaks position shifted upwards at further to evacuation up to $150^{\circ} \mathrm{C}$. This shift indicated that the species, a Lewis coordinated one, were most sensitive to coverage effects ${ }^{19}$. An attempt has also been made to quantitatively estimate the number of Lewis acid sites for the oxides using pyridine adsorption followed by degassing at 20 and $150^{\circ} \mathrm{C}$ according to the described method (Table 1$)^{20}$. After degassing at $20^{\circ} \mathrm{C}$, the total amount of Lewis acid sites of the $\mathrm{Fe}_{3} \mathrm{O}_{4}$, and $\alpha-\mathrm{FeOOH}$ were 307.6 and $795.4 \mu \mathrm{mol} \mathrm{g}^{-1}$, respectively. After degassing at $150^{\circ} \mathrm{C}$, however, there were hardly any Lewis acid sites on the surface of $\mathrm{Fe}_{3} \mathrm{O}_{4}$, and the Lewis acid amount were decreased to $106.7 \mu \mathrm{mol} \mathrm{g}^{-1}$ for $\alpha-\mathrm{FeOOH}$, indicating that main weak Lewis acid sites were on the surface of $\mathrm{Fe}_{3} \mathrm{O}_{4}$, and $\alpha-\mathrm{FeOOH}$.

By a saturated deprotonation method the surface hydroxyl density (Ns) of the prepared oxides was measured. The Ns of $\alpha-\mathrm{Fe}_{2} \mathrm{O}_{3}, \alpha-\mathrm{FeOOH}$ and $\mathrm{Fe}_{3} \mathrm{O}_{4}$ were 57,330 , and $116 \mathrm{mmolg}^{-1}$, respectively (Table 1). Furthermore, to distinguish the surface hydroxyl groups of catalyst from water, the heavy water $\left(\mathrm{D}_{2} \mathrm{O}\right)$ instead of $\mathrm{H}_{2} \mathrm{O}$ was used in ATR-FTIR experiments. As shown in Fig. 3, two hydroxyl absorbance peaks around 2308 and $2573 \mathrm{~cm}^{-1}$ for $\alpha-\mathrm{Fe}_{2} \mathrm{O}_{3}$ were attributed to surface isolated hydroxyl and hydrogen-bonded hydroxyl groups ${ }^{10,18}$. The IR bands at 2300 and $2488 \mathrm{~cm}^{-1}$ for $\mathrm{Fe}_{3} \mathrm{O}_{4}$ were isolated hydroxyl and hydrogen-bonded hydroxyl on weak Lewis acid sites ${ }^{21}$. The IR bands at 2360 and $2480 \mathrm{~cm}^{-1}$ for $\alpha-\mathrm{FeOOH}$ were bridged hydroxyl groups on strong Lewis acid sites and 

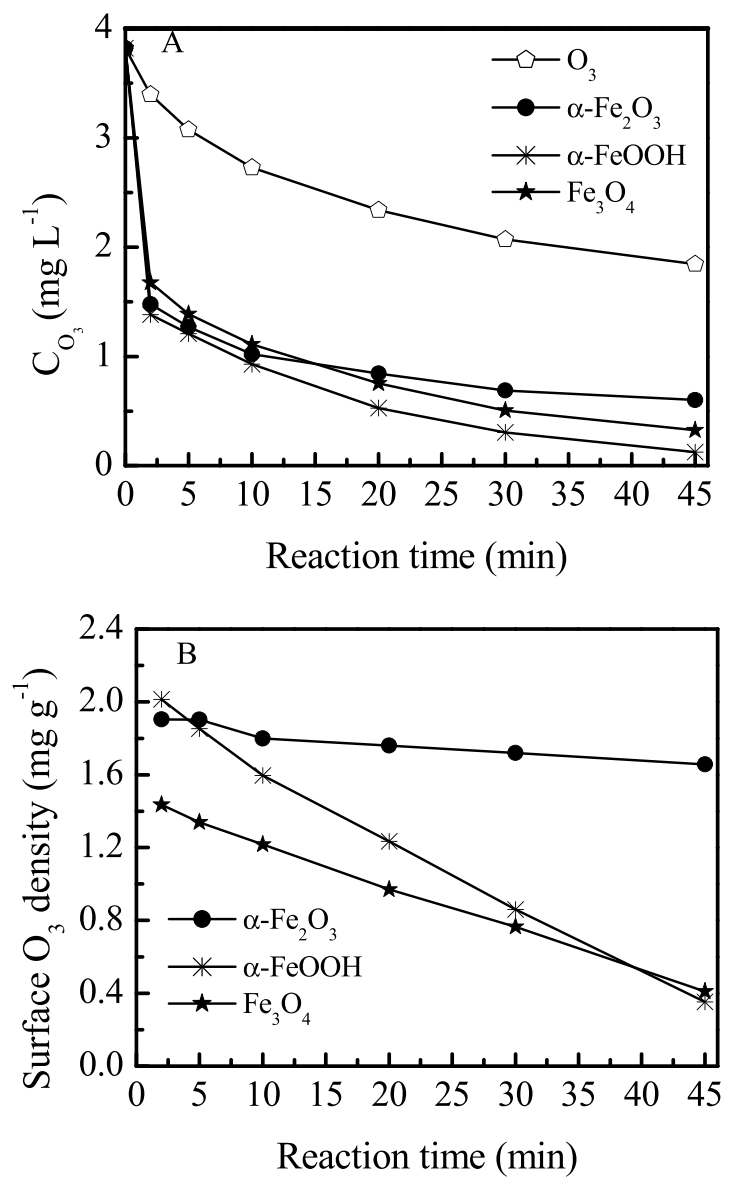

Figure 4. The changes of ozone concentration with time in bulk water (A) and the surface of iron oxides (B) in different processes. (Catalyst dose: $1.5 \mathrm{~g} \mathrm{~L}^{-1}$, initial $\mathrm{pH}: 7.0$ ).

hydrogen-bonded hydroxyl on weak Lewis acid sites, respectively ${ }^{22}$. The surface properties of iron oxides determine the behavior of ozone at different surface sites.

Adsorption and decomposition of ozone onto different iron oxides in water. Surface adsorption curve of ozone on different oxides was shown in Fig. 4. The concentration of ozone decreased rapidly in oxide suspensions than $\mathrm{O}_{3}$ alone aqueous solution due to adsorption of the catalyst at 2 min (Fig. 4A), then the concentration of ozone continuously decreased with reaction time. $\alpha-\mathrm{FeOOH}$ had the highest decay rate of ozone. Figure 4B showed the changes of ozone concentration on the surface of the oxides. At 2 min reaction time, the $\mathrm{O}_{3}$ adsorption amount was $1.91,2.01$ and $1.43 \mathrm{mg} \mathrm{g}^{-1}$ for $\alpha-\mathrm{Fe}_{2} \mathrm{O}_{3}, \alpha-\mathrm{FeOOH}$ and $\mathrm{Fe}_{3} \mathrm{O}_{4}$, respectively. Then the concentration of ozone tends to steady in $\alpha-\mathrm{Fe}_{2} \mathrm{O}_{3}$ suspension after $10 \mathrm{~min}$. On the contrast, the concentration of ozone continuously decreased in $\alpha-\mathrm{FeOOH}$ and $\mathrm{Fe}_{3} \mathrm{O}_{4}$ suspensions with reaction time, indicating these two oxides contribute to the decomposition of ozone.

Figure 5 shows the $\mathrm{D}_{2} \mathrm{O}$ hydroxylation of iron oxides with bubbling ozone by in-situ ATR-FTIR. Obviously, in $\alpha-\mathrm{Fe}_{2} \mathrm{O}_{3}$ suspension, with increasing bubbling ozone time, the intensities of the peaks of surface isolated hydroxyl $\left(2308 \mathrm{~cm}^{-1}\right)$ and hydrogen-bonded hydroxyl $\left(2573 \mathrm{~cm}^{-1}\right)$ hardly had any change, revealing that the hydroxyl groups in the non acidic sites cannot be replaced by ozone, indicating that ozone was electrostatically adsorbed on these surface hydroxyl groups. Also, in $\mathrm{Fe}_{3} \mathrm{O}_{4}$ suspension, the intensities of these isolated hydroxyl peaks at $2300 \mathrm{~cm}^{-1}$ hardly had any changed with the constant contact with ozone. The results verified that these isolated hydroxyls also could not exchange with ozone on $\mathrm{Fe}_{3} \mathrm{O}_{4}$. While the peak of hydrogen-bonded hydroxyl on weak Lewis acid sites at $2488 \mathrm{~cm}^{-1}$ for $\mathrm{Fe}_{3} \mathrm{O}_{4}$, bridged hydroxyl groups and hydrogen-bonded hydroxyl on Lewis acid sites at 2360 and $2480 \mathrm{~cm}^{-1}$ for $\alpha-\mathrm{FeOOH}$ decreased gradually, indicating that the hydroxyl groups were replaced by ozone by competition with water, although water seems to be a stronger Lewis base than ozone molecule. These results show that all the isolated hydroxyls and hydrogen-bonded hydroxyl on non acidic sites cannot be substituted by ozone, while ozone can replace hydroxyl groups in Lewis acidic sites and decompose effectively. Furthermore, the $\mathrm{pH}_{\text {pzc }}$ of $\alpha-\mathrm{Fe}_{2} \mathrm{O}_{3}, \alpha-\mathrm{FeOOH}$ and $\mathrm{Fe}_{3} \mathrm{O}_{4}$ was 7.2, 8.6 and 6.8, respectively (Table 1). However, the adsorption and decomposition of ozone on the oxide surfaces was not directly related to the $\mathrm{pH}_{\mathrm{pzc}}$, which only depends on the hydroxyl groups of Lewis acid sites on the surface of the oxides.

Ozone transformation on the surface of different iron oxides. EPR spin-trap technique was used to analyze the ROS with ozone decomposition in these iron oxide suspensions. As illustrated in Fig. 6, neither 

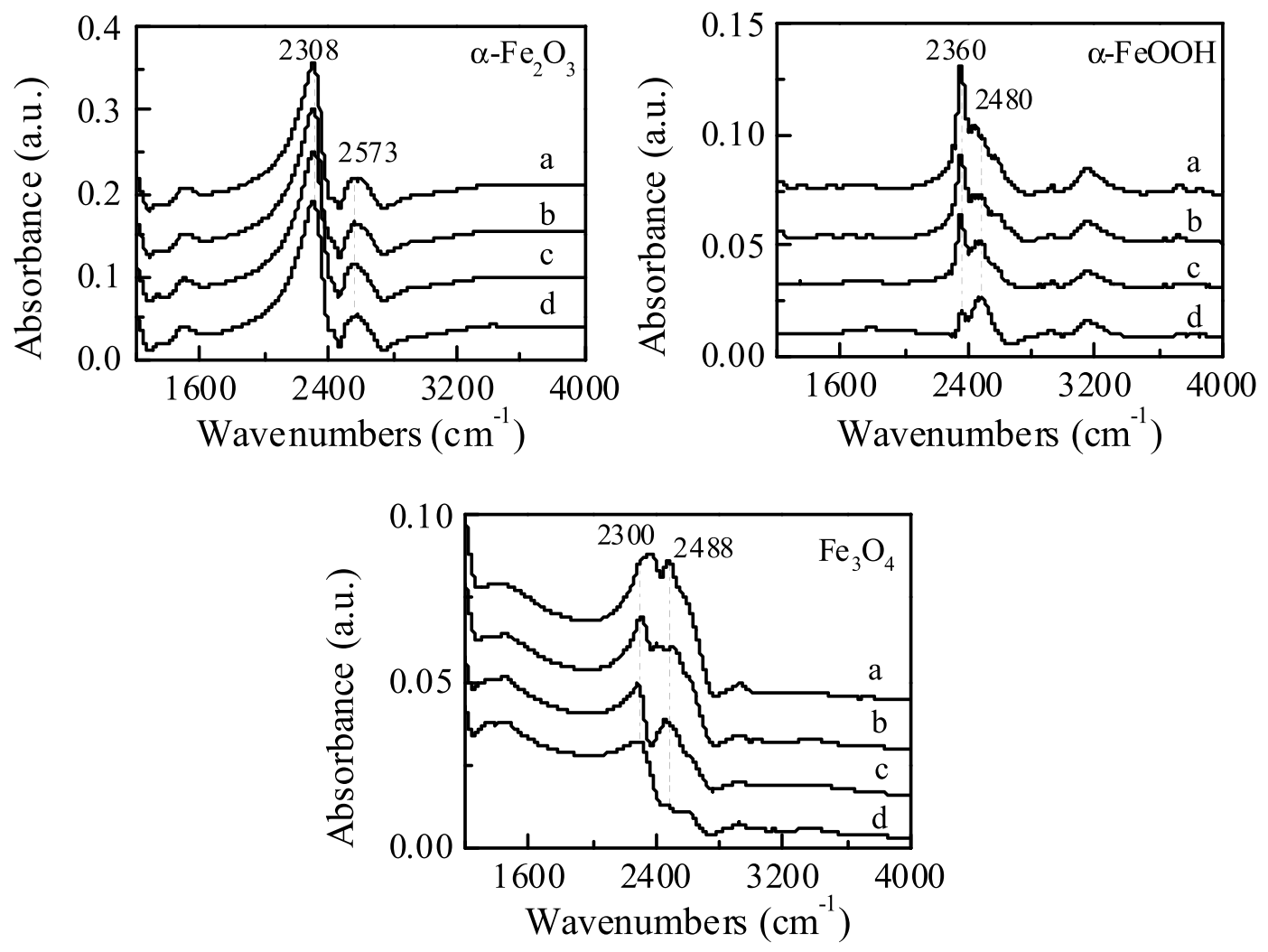

Figure 5. ATR-FTIR spectra of iron oxides suspended in $\mathrm{D}_{2} \mathrm{O}$ bubbling ozone for different time: (a) 0 min, (b) $2 \mathrm{~min}$, (c) $5 \mathrm{~min}$ and (d) $10 \mathrm{~min}$. (catalyst dose: $100 \mathrm{gL}^{-1}, \mathrm{pD}: 7.0$ ).

$\mathrm{O}_{2}{ }^{\bullet-}$ nor ${ }^{\bullet} \mathrm{OH}$ signals were detected in $\alpha-\mathrm{Fe}_{2} \mathrm{O}_{3}$ suspension. The results confirmed that the physics-sorbed ozone was stable on the surface of $\alpha-\mathrm{Fe}_{2} \mathrm{O}_{3}$, which is consistent with the results of the adsorption and decomposition of ozone on $\alpha-\mathrm{Fe}_{2} \mathrm{O}_{3}$ surface in water, indicating that ozone was direct oxidant in $\alpha-\mathrm{Fe}_{2} \mathrm{O}_{3}$ suspesnsion. Both higher $\mathrm{O}_{2}{ }^{-}$and $\bullet \mathrm{OH}$ signals were observed in $\alpha-\mathrm{FeOOH}$ and $\mathrm{Fe}_{3} \mathrm{O}_{4}$ suspensions, and the signal strength of $\alpha-\mathrm{FeOOH}$ is larger than that of $\mathrm{Fe}_{3} \mathrm{O}_{4}$. The results were consistent with the ozone decomposition rate in different oxides suspensions (Fig. 4), demonstrating that ozone decay was accompanied by the generation of $\mathrm{O}_{2}^{\bullet-}$ and ${ }^{\bullet} \mathrm{OH}$. In order to further clarify the mechanism of $\mathrm{O}_{2}{ }^{\bullet-}$ and ${ }^{\bullet} \mathrm{OH}$ generation on the surface of oxides with the decomposition of ozone, isotope ${ }^{18} \mathrm{O}_{3}$ instead of ${ }^{16} \mathrm{O}_{3}$ was used in EPR studies of iron oxides suspensions. Compared the EPR spectra of the ${ }^{18} \mathrm{O}_{3}$ with those of ${ }^{16} \mathrm{O}_{3}$, the position of BMPO- ${ }^{\bullet} \mathrm{OH}$ signals did not change, while BMPO-O ${ }_{2}{ }^{--}$signal broadening in $\mathrm{O}_{3}$ alone aqueous solution (Fig. 7) ${ }^{23}$. The results confirm that reactions (1-2) are the main reactions in ozonation process ${ }^{24}$.

$$
\begin{gathered}
{ }^{18} \mathrm{O}_{3}+\mathrm{HO}^{-} \rightarrow{ }^{18} \mathrm{O}_{2}^{--}+\mathrm{HO}^{18} \mathrm{O}, \quad \mathrm{k}_{2}=70 \mathrm{M}^{-1} \mathrm{~s}^{-1} \\
{ }^{18} \mathrm{O}_{3}+\mathrm{HO}_{2} \Leftrightarrow{ }^{18} \mathrm{O}_{2}+{ }^{18} \mathrm{OO}+\mathrm{HO}, \mathrm{k}_{2}=1.6 \times 10^{9} \mathrm{M}^{-1} \mathrm{~s}^{-1}
\end{gathered}
$$

In $\alpha-\mathrm{FeOOH}$ and $\mathrm{Fe}_{3} \mathrm{O}_{4}$ aqueous dispersion containing ${ }^{18} \mathrm{O}_{3}$, both $\mathrm{O}_{2}{ }^{\bullet-}$ and ${ }^{\bullet} \mathrm{OH}$ signals became broadening, indicating that the hydroxyl radical and superoxide radical originated from the decomposition of ${ }^{18} \mathrm{O}_{3}$ molecule on the surface of the oxides. This may be due to the electron cycle of $\mathrm{Fe}^{2+} / \mathrm{Fe}^{3+}$ involved in the reaction of ozone decomposition. To ascertain the conjecture, the $\mathrm{Fe}^{2+}$ concentrations on the surface of $\alpha-\mathrm{Fe}_{2} \mathrm{O}_{3}, \alpha-\mathrm{FeOOH}$ and $\mathrm{Fe}_{3} \mathrm{O}_{4}$ at different reaction time were measured (Fig. 8). $\mathrm{No} \mathrm{Fe}^{2+}$ was detected on $\alpha-\mathrm{Fe}_{2} \mathrm{O}_{3}$ surface with ozone solution, confirming that $\mathrm{Fe}^{2+}$ was not involved in the reaction. The results indicated that the surface isolated hydroxyl groups and hydrogen-bonded hydroxyl on the surface of $\alpha-\mathrm{Fe}_{2} \mathrm{O}_{3}$, blocked that ozone directly interacted with the surface $\mathrm{Fe}^{3+}$, keeping the adsorbed ozone stable, which was adsorbed by electrostatic forces. Differently, in $\alpha-\mathrm{FeOOH}$ suspension with ozone, the produced surface $\mathrm{Fe}^{2+}$ concentration increased with reaction time and tended to be stable at about 20 min. In $\mathrm{Fe}_{3} \mathrm{O}_{4}$ suspension with ozone, there was high $\mathrm{Fe}^{2+}$ concentration at the beginning of the reaction, then decreased to be oxidized to $\mathrm{Fe}^{3+}$ with prolonged reaction time. The results indicated that the adsorbed ozone on the Lewis acid sites directly reacted with the surface $\mathrm{Fe}^{3+}$ of $\alpha-\mathrm{FeOOH}$ and $\mathrm{Fe}_{3} \mathrm{O}_{4}$, enhancing the formation of ${ }^{\bullet} \mathrm{OH}$ and $\mathrm{O}_{2}{ }^{-}$radicals. In light of the experimental data, a mechanism scheme is proposed for the ozone decomposition at the Lewis acids of $\alpha-\mathrm{FeOOH}$ and $\mathrm{Fe}_{3} \mathrm{O}_{4}$. The main reactions are shown in Eqs (3-5).

$$
\equiv \mathrm{Fe}^{3+}-\mathrm{OH}+{ }^{18} \mathrm{O}_{3} \rightarrow \equiv \mathrm{Fe}^{3+}-{ }^{18} \mathrm{O}_{3}+\mathrm{OH}^{-}
$$



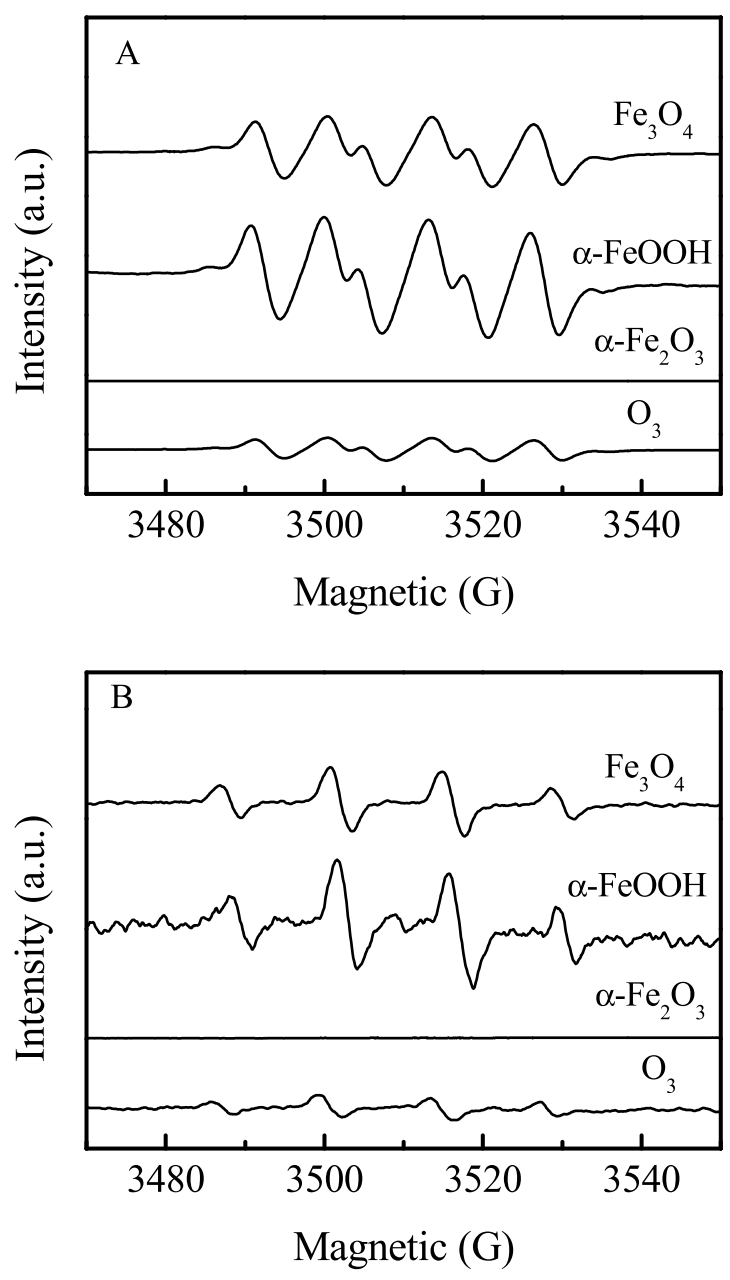

Figure 6. EPR signal in methanol dispersion for $\mathrm{BMPO}-\mathrm{HO}_{2}{ }^{\bullet} \mathrm{O}_{2}{ }^{--}(\mathbf{A})$ and aqueous dispersion for BMPO$\bullet \mathrm{OH}(\mathbf{B})$ with ozone.

$$
\begin{gathered}
\equiv \mathrm{Fe}^{3+}-{ }^{18} \mathrm{O}_{3}+\mathrm{OH}^{-} \rightarrow \equiv \mathrm{Fe}^{2+}+\mathrm{HO}^{18} \mathrm{O}+{ }^{18} \mathrm{O}_{2} \\
\equiv \mathrm{Fe}^{2+}+{ }^{18} \mathrm{O}_{3}+\mathrm{H}_{2} \mathrm{O} \rightarrow \equiv \mathrm{Fe}^{3+}-\mathrm{OH}+{ }^{\cdot 18} \mathrm{OH}+{ }^{18} \mathrm{O}_{2}
\end{gathered}
$$

Catalytic ozonation of ibuprofen in different iron oxide suspensions. The catalytic activity of the oxides was evaluated by ibuprofen. The adsorption removal of ibuprofen by $\alpha-\mathrm{Fe}_{2} \mathrm{O}_{3}, \mathrm{Fe}_{3} \mathrm{O}_{4}$ and $\alpha-\mathrm{FeOOH}$ were about $5 \%, 3 \%$ and $6 \%$ in equilibrium, respectively (Fig. S1). The comparison of ibuprofen and TOC removal among different iron oxide suspensions were shown in Fig. 9. The presence of catalyst was advantageous for ibuprofen degradation compared with ozonation alone, and $\alpha-\mathrm{FeOOH}$ had the highest catalytic activity. The ozonation of ibuprofen led to $26 \%$ TOC removal at $60 \mathrm{~min}$. The simultaneous use of ozone and $\alpha-\mathrm{Fe}_{2} \mathrm{O}_{3}$ slightly increased ibuprofen removal, TOC removal was increased to $32 \%$. In the $\alpha-\mathrm{FeOOH} / \mathrm{O}_{3}$ process, a maximum of $62 \%$ TOC removal was obtained at 60 min oxidation time, while about $52 \%$ of TOC were removed at the same time in $\mathrm{Fe}_{3} \mathrm{O}_{4} / \mathrm{O}_{3}$ process. Because only $6 \%$ TOC removal by $\alpha-\mathrm{FeOOH}$ adsorption. It indicated that there was a significant synergetic effect (between $\alpha-\mathrm{FeOOH}$ adsorption and ozonation alone in $\alpha-\mathrm{FeOOH} / \mathrm{O}_{3}$ process). Furthermore, the catalytic activity of different iron oxides was consistent with the amount of surface Lewis acid site. The results indicate that Lewis acid sites were active center, which causes the effective decomposition of ozone. While the electronic cycle of the $\mathrm{Fe}^{2+}$ / $\mathrm{Fe}^{3+}$ was advantageous to promote ozone decomposition into $\mathrm{O}_{2}{ }^{--}$and ${ }^{\bullet} \mathrm{OH}$ radicals, leading to effective degradation and mineralization of ibuprofen. These finding provided a new sight for the mechanism of catalytic ozonation and the design of new type heterogeneous catalytic ozonation catalyst.

\section{Conclusions}

Three iron oxides were prepared, which are $\alpha-\mathrm{Fe}_{2} \mathrm{O}_{3}, \alpha-\mathrm{FeOOH}$ and $\mathrm{Fe}_{3} \mathrm{O}_{4}$. These iron oxides have different acid sites and thus different hydroxyl groups. $\alpha-\mathrm{Fe}_{2} \mathrm{O}_{3}$ has no acid sites. Ozone was electrostatic adsorbed stably at isolated hydroxyl and hydrogen-bonded hydroxyl on $\alpha-\mathrm{Fe}_{2} \mathrm{O}_{3}$, and did not react with the surface $\mathrm{Fe}^{3+}$ ions due to blocking by these hydroxyl groups. Different mechanisms were observed for $\alpha-\mathrm{FeOOH}$ and $\mathrm{Fe}_{3} \mathrm{O}_{4}$, ozone was 

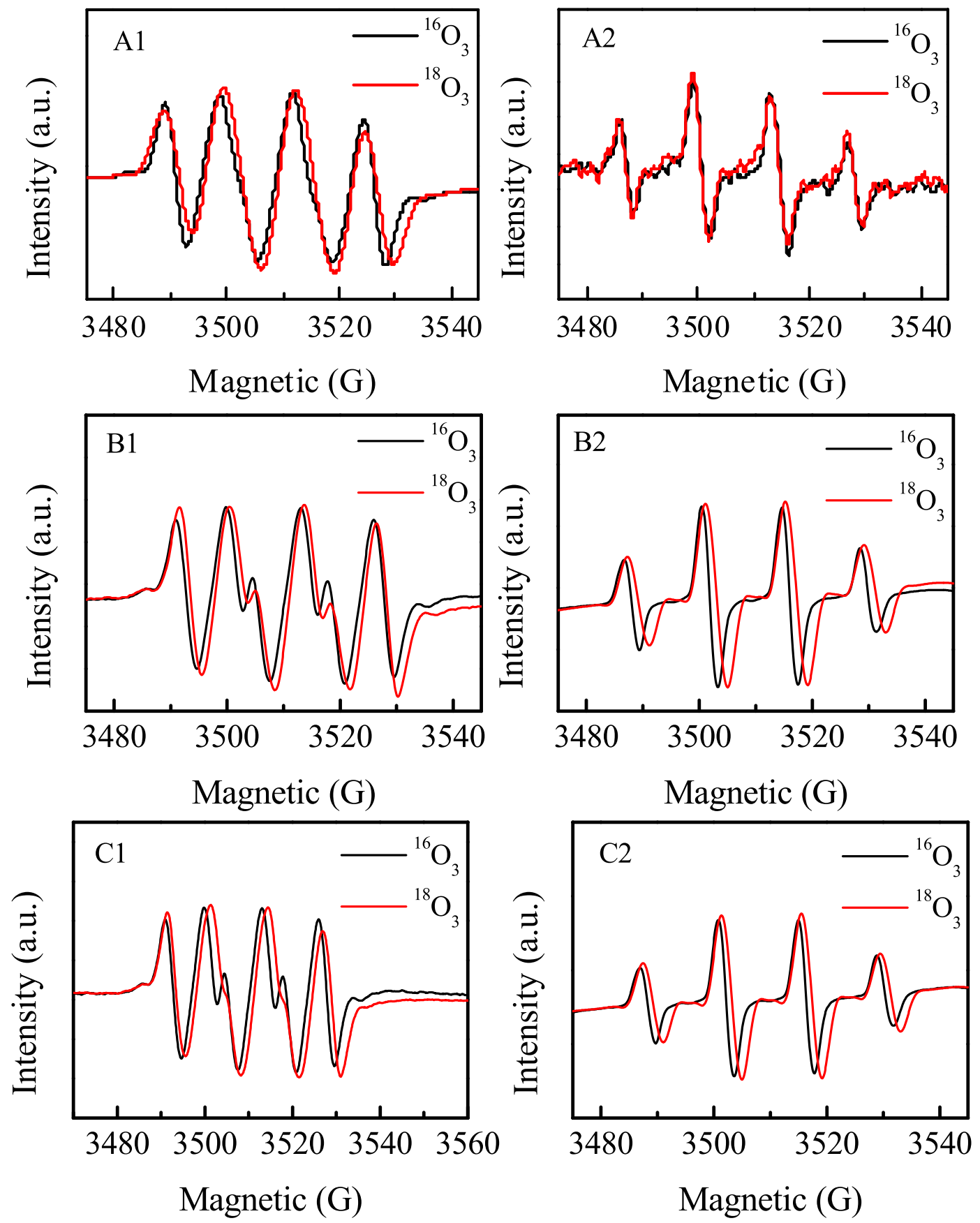

Figure 7. EPR spectra of $\mathrm{O}_{3}$ alone $(\mathbf{A}), \alpha-\mathrm{FeOOH}(\mathbf{B})$ and $\mathrm{Fe}_{3} \mathrm{O}_{4}(\mathbf{C})$ recorded in methanol dispersion for BMPO- $\mathrm{HO}_{2}{ }^{\bullet} / \mathrm{O}_{2}{ }^{\bullet-}(\mathrm{A} 1, \mathrm{~B} 1$ and $\mathrm{C} 1)$ and aqueous dispersion for BMPO- ${ }^{\bullet} \mathrm{OH}\left(\mathrm{A} 2\right.$, B2 and C2) with ${ }^{16} \mathrm{O}_{3}$ or ${ }^{18} \mathrm{O}_{3}$.

adsorbed on the surface Lewis acid sites of $\alpha$-FeOOH and $\mathrm{Fe}_{3} \mathrm{O}_{4}$ competing with water, directly interacted with the surface $\mathrm{Fe}^{3+}$ ions and mainly converted into $\mathrm{O}_{2}{ }^{--}$and ${ }^{\bullet} \mathrm{OH}$ due to $\mathrm{Fe}^{2+} / \mathrm{Fe}^{3+}$ electronic circulation when ozone adsorbed on $\alpha-\mathrm{FeOOH}$ and $\mathrm{Fe}_{3} \mathrm{O}_{4}$.

\section{Experimental Section}

Preparation of catalysts. The $\alpha-\mathrm{FeOOH}$ particles were prepared by adding $1.0 \mathrm{~mol} \mathrm{~L}^{-1}$ sodium hydroxide solution to $0.1 \mathrm{~mol} \mathrm{~L}^{-1}$ ferric nitrate solution containing $20 \mathrm{~mol} \%$ amounts of sodium citrate up to $\mathrm{pH} 12$, in a polypropylene screwcapped vessel at room temperature. The resulting precipitates were aged for 4 days in a thermostat at $30^{\circ} \mathrm{C}$. The precipitates were thoroughly washed with water and dried in air at $70^{\circ} \mathrm{C}$ for $16 \mathrm{~h}^{25}$. Magnetite $\mathrm{Fe}_{3} \mathrm{O}_{4}$ was prepared from the precipitate of ferric nitrate solution with aqueous sodium hydroxide ${ }^{26}$. The precipitate was washed with ammonium acetate solution, dried at $100^{\circ} \mathrm{C}$ for $12 \mathrm{~h}$, and treated at $400^{\circ} \mathrm{C}$ under an atmosphere of $\mathrm{N}_{2}$ for $2 \mathrm{~h}$. $\alpha-\mathrm{Fe}_{2} \mathrm{O}_{3}$ was synthesized by calcining a precursor of ferrous oxalate, which was precipitated from a Fe ${ }^{2+}$ solution mixed with oxalic acid ${ }^{27}$. 


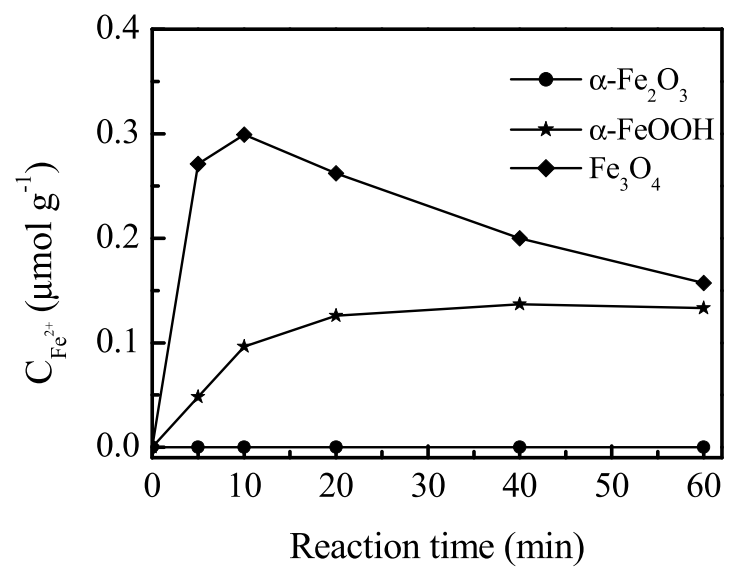

Figure 8. The concentration of surface $\mathrm{Fe}^{2+}$ on $\alpha-\mathrm{Fe}_{2} \mathrm{O}_{3}, \mathrm{Fe}_{3} \mathrm{O}_{4}$ and $\alpha-\mathrm{FeOOH}$ aqueous dispersions during catalytic ozonation process. (Initial $\mathrm{pH}$ : 7.0, catalyst concentration: $1.5 \mathrm{~g} \mathrm{~L}^{-1}$ ).
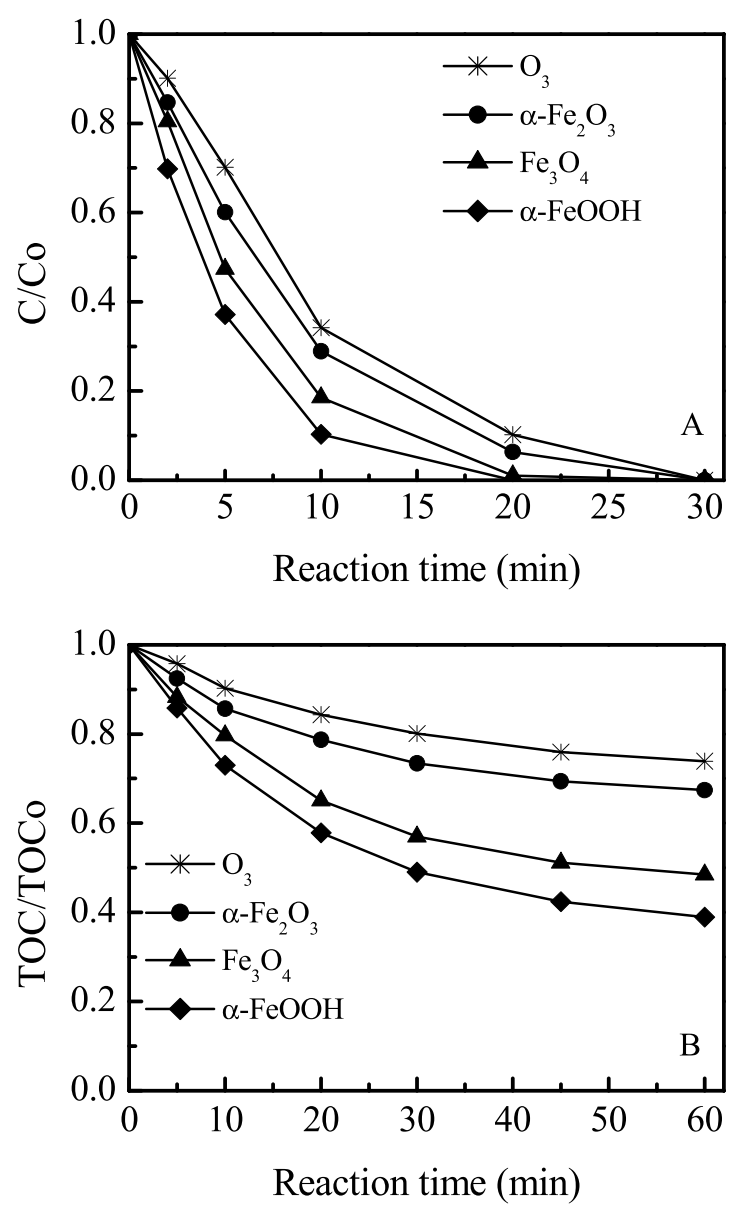

Figure 9. (A) Catalytic ozonation of IBU in various suspensions. (B) TOC removal. (Initial $\mathrm{pH}=7.0$, initial IBU concentration $=10 \mathrm{mg} \mathrm{L}^{-1}$, catalyst concentration $=1.5 \mathrm{~g} \mathrm{~L}^{-1}$, gaseous ozone concentration $\left.=30 \mathrm{mg} \mathrm{L}^{-1}\right)$.

Characterization. Powder X-ray diffraction (XRD) of the catalyst was analyzed on a Scintag-XDS-2000 diffractometer with $\mathrm{Cu} \mathrm{K \alpha}$ radiation $\left(\lambda=1.540598 \AA\right.$ ). BET-surface areas were measured by $\mathrm{N}_{2}$ adsorption using a Micromeritics ASAP2020 automated gas sorption system (USA). Infrared spectra of adsorbed pyridine (Py-FTIR) were taken on a Bruker Tensor 27 FT-IR spectrometer. The samples were pressed into self-supporting wafers and were evacuated in a vacuum cell at $100^{\circ} \mathrm{C}$ for $2 \mathrm{~h}$. The infrared spectra of adsorbed pyridine were recorded after degassing at $20^{\circ} \mathrm{C}$ and $150^{\circ} \mathrm{C}$. The point of zero charge $\left(\mathrm{pH}_{\mathrm{pzc}}\right)$ of the catalysts was determined with a Zetasizer Nano (Malvern, UK). The surface hydroxyl density (Ns) of catalysts was measured according to a saturated deprotonation method ${ }^{28}$. 
Experimental procedures. The concentration of ozone in the process of catalytic ozonation and catalyst surface was analyzed by improved indigo method ${ }^{29}$. Ozone decomposition experiments were carried out in a $250 \mathrm{~mL}$ three-mouth flask at $20^{\circ} \mathrm{C}$. Ozone was generated by a 3S-A5 laboratory ozone generator (Tonglin Technology, China). Firstly, ozone was continuously bubbled into $250 \mathrm{~mL}$ of water to get ozone saturated aqueous solution $\left(3.82 \mathrm{mg} \mathrm{L}^{-1}\right)$. After $0.375 \mathrm{~g}$ of catalyst was added, the time counting was immediately started. Addition of catalysts almost had no effect on the solution $\mathrm{pH}(7 \pm 0.1)$. At given time intervals, $1 \mathrm{~mL}$ suspensions were collected and $1 \mathrm{~mL}$ filtrate was obtained at the same time, then it was added into $8 \mathrm{~mL}$ indigo solution respectively. The samples were mixed, filtered through a $0.22 \mu \mathrm{m}$ Millipore filter for ozone concentration measurement. In the determination experiment, all catalysts hardly adsorb any indigo, and in order to reduce the impact of filtration on aqueous ozone, $60 \mathrm{~mL}$ of the ozone stock solution was pressed through the filter before sample filtration, so the ozone concentration was not affected by the filtration process.

The catalytic reaction procedure was carried out in a $1.2 \mathrm{~L}$ column reactor at $20^{\circ} \mathrm{C}$. In a typical procedure, $1 \mathrm{~L}$ ibuprofen around $10 \mathrm{mg} \mathrm{L}^{-1}$ aqueous solution and $1.5 \mathrm{~g}$ of catalyst powder were mixed in the reactor under continuously magnetically stir. Ozone was produced in situ from pure oxygen by a 3S-A5 laboratory ozone generator (Tonglin Technology, China). Gaseous $\mathrm{O}_{3}\left(30 \mathrm{mg} \mathrm{L}^{-1}\right)$ was continuously bubbled into the reactor through the porous plate of the reactor bottom at a $200 \mathrm{~mL} \mathrm{~min}^{-1}$ flow rate. The excess ozone in the outlet gas was trapped by a $\mathrm{Na}_{2} \mathrm{~S}_{2} \mathrm{O}_{3}$ solution. The same procedures were carried out for the control experiments of ozone alone and sorption without ozone. Water samples were taken at regular intervals. A $0.1 \mathrm{~mol} \mathrm{~L}^{-1} \mathrm{Na}_{2} \mathrm{~S}_{2} \mathrm{O}_{3}$ solution was used to quench the continuous ozonation reaction in the new withdrawn water samples and then water samples were filtered by a $0.45 \mu \mathrm{m}$ Millipore filter to analyze ibuprofen and total organic carbon (TOC) concentrations.

Analytical methods. The ozone concentration in the gas phase is determined by an IDEAL-2000 ozone concentration detector (China). The concentration of ibuprofen was analyzed by means of an Agilent 1200 series HPLC equipped with a UV detector at $220 \mathrm{~nm}$ and a ZORBAX Eclipse XDB-C18 column $(4.6 \times 150 \mathrm{~mm}, 5 \mu \mathrm{m})$. Total organic carbon (TOC) was measured by a Shimadzu TOC- $\mathrm{V}_{\mathrm{CPH}}$ analyzer. Electron paramagnetic resonance (EPR) spectra were recorded at $20^{\circ} \mathrm{C}$ on a Bruker A300-10/12 EPR spectrometer using 5-tert-Butoxycarbonyl-5 -methyl-1-pyrroline-N-oxide (BMPO) as a spin trap agent. The ATR-FTIR spectra were measured with a Nicolet 8700 FTIR spectrophotometer (Thermo Fisher Scientific Inc., USA) equipped with a Universal ATR accessory. The ATR-FTIR samples were prepared as described previously ${ }^{22}$. The $\mathrm{Fe}^{2+}$ concentrations on the surface of $\alpha-\mathrm{Fe}_{2} \mathrm{O}_{3}$, $\alpha-\mathrm{FeOOH}$ and $\mathrm{Fe}_{3} \mathrm{O}_{4}$ at different reaction time were measured by a modified 1,10-phenanthroline method at a wavelength of $510 \mathrm{~nm}$ using a UV-vis spectrophotometer (U-3900, HITACHI). The 1, 10-Phenanthroline could take up $\mathrm{Fe}^{2+}$ from the surface of the solid phase via a specific chelating reaction ${ }^{30}$. In a typical process, the catalyst dispersions under different reaction time were filtered and the resulting solid was re-suspended in $10 \mathrm{~mL}$ of 1 , 10-phenanthroline solution $\left(\mathrm{g} \mathrm{L}^{-1}\right)$ and reaction for $10 \mathrm{~min}$, the new dispersion was filtered and the filtrates were analyzed at $\lambda=510 \mathrm{~nm}$, which is the maximal adsorption wavelength for $\mathrm{Fe}^{2+}-1,10$-phenanthroline complex.

\section{References}

1. Lee, Y. et al. Prediction of micropollutant elimination during ozonation of municipal wastewater effluents: Use of kinetic and water specific information. Environ. Sci. Technol. 47, 5872-5881 (2013).

2. Nawrocki, J. \& Kasprzyk-Hordern, B. The efficiency and mechanisms of catalytic ozonation. Appl. Catal., B 99, 27-42 (2010).

3. Legube, B. \& Karpel Vel, L. N. Catalytic ozonation: a promising advanced oxidation technology for water treatment. Catal. Today 53, 61-72 (1999)

4. Lin, J., Kawai, A. \& Nakajima, T. Effective catalysts for decomposition of aqueous ozone. Appl. Catal., B 39, 157-165 (2002).

5. Zhang, T., Li, W. \& Croué, J.-P. Catalytic ozonation of oxalate with a cerium supported palladium oxide: An efficient degradation not relying on hydroxyl radical oxidation. Environ. Sci. Technol. 45, 9339-9346 (2011).

6. Nawrocki, J. Catalytic ozonation in water: Controversies and questions. Discussion paper. Appl. Catal., B 142-143, 465-471 (2013).

7. Chen, H., Stanier, C. O., Young, M. A. \& Grassian, V. H. A kinetic study of ozone decomposition on illuminated oxide surfaces. J. Phys. Chem. A 115, 11979-11987 (2011).

8. Roscoe, J. M. \& Abbatt, J. P. D. Diffuse reflectance FTIR study of the interaction of alumina surfaces with ozone and water vapor. J. Phys. Chem. A 109, 9028-9034 (2005).

9. Tamura, H., Tanaka, A., Mita, K.-y \& Furuichi, R. Surface hydroxyl site densities on metal oxides as a measure for the ion-exchange capacity. J. Colloid Interface Sci. 209, 225-231 (1999).

10. Noei, H. et al. The identification of hydroxyl groups on ZnO nanoparticles by infrared spectroscopy. Phys. Chem. Chem. Phys. 10, $7092-7097$ (2008).

11. Nanayakkara, C. E., Larish, W. A. \& Grassian, V. H. Titanium dioxide nanoparticle surface reactivity with atmospheric gases, $\mathrm{CO}_{2}$, $\mathrm{SO}_{2}$, and $\mathrm{NO}_{2}$ : Roles of surface hydroxyl groups and adsorbed water in the formation and stability of adsorbed products. J. Phys. Chem. C 118, 23011-23021 (2014).

12. Tang, D. \& Zhang, G. Efficient removal of fluoride by hierarchical Ce-Fe bimetal oxides adsorbent: Thermodynamics, kinetics and mechanism. Chem. Eng. J. 283, 721-729 (2016).

13. Tamura, H., Mita, K., Tanaka, A. \& Ito, M. Mechanism of Hydroxylation of Metal Oxide Surfaces. J. Colloid Interface Sci. 243 , 202-207 (2001)

14. Bulanin, K. M., Lavalley, J. C. \& Tsyganenko, A. A. IR spectra of adsorbed ozone. Colloids Surf., A 101, 153-158 (1995).

15. Zhao, L., Sun, Z. \& Ma, J. Novel Relationship between Hydroxyl Radical Initiation and Surface Group of Ceramic Honeycomb Supported Metals for the Catalytic Ozonation of Nitrobenzene in Aqueous Solution. Environ. Sci. Technol. 43, 4157-4163 (2009).

16. Zhang, T., Li, C., Ma, J., Tian, H. \& Qiang, Z. Surface hydroxyl groups of synthetic $\alpha-F e O O H$ in promoting OH generation from aqueous ozone: Property and activity relationship. Appl. Catal., B 82, 131-137 (2008).

17. Bing, J., Hu, C., Nie, Y., Yang, M. \& Qu, J. Mechanism of Catalytic Ozonation in $\mathrm{Fe}_{2} \mathrm{O}_{3} / \mathrm{Al}_{2} \mathrm{O}_{3} @ S B A-15$ Aqueous Suspension for Destruction of Ibuprofen. Environ. Sci. Technol. 49, 1690-1697 (2015).

18. Lorenzelli, V. \& Busca, G. Infrared studies of the surface of $\alpha-\mathrm{Fe}_{2} \mathrm{O}_{3}$. Mater. Chem. Phys. 13, 261-281 (1985).

19. Morterra, C., Mirra, C. \& Borello, E. IR spectroscopic study of pyridime adsorption onto $\alpha$-FeOOH (goethite). Mater. Chem. Phys. 10, 139-154 (1984)

20. Emeis, C. A. Determination of Integrated Molar Extinction Coefficients for Infrared Absorption Bands of Pyridine Adsorbed on Solid Acid Catalysts. J. Catal. 141, 347-354 (1993). 
21. Rim, K. T. et al. Scanning Tunneling Microscopy and Theoretical Study of Water Adsorption on $\mathrm{Fe}_{3} \mathrm{O}_{4}$ : Implications for Catalysis. J. Am. Chem. Soc. 134, 18979-18985 (2012).

22. Tejedor-Tejedor, M. I. \& Anderson, M. A. "In situ" ATR-Fourier transform infrared studies of the goethite $(\alpha-\mathrm{FeOOH})$-aqueous solution interface. Langmuir 2, 203-210 (1986).

23. McConnell, I. L. et al. EPR-ENDOR Characterization of $(17 \mathrm{O}, 1 \mathrm{H}, 2 \mathrm{H})$ Water in Manganese Catalase and Its Relevance to the Oxygen-Evolving Complex of Photosystem II. J. Am. Chem. Soc. 134, 1504-1512 (2012).

24. Kasprzyk-Hordern, B., Ziółek, M. \& Nawrocki, J. Catalytic ozonation and methods of enhancing molecular ozone reactions in water treatment. Appl. Catal., B 46, 639-669 (2003).

25. Kandori, K., Fukuoka, M. \& Ishikawa, T. Effects of citrate ions on the formation of ferric oxide hydroxide particles. J. Mater. Sci. 26, 3313-3319 (1991).

26. Oliveira, L. C. A., Fabris, J. D., Rios, R. R. V. A., Mussel, W. N. \& Lago, R. M. $\mathrm{Fe}_{3-\mathrm{x}} \mathrm{Mn}_{\mathrm{x}} \mathrm{O}_{4}$ catalysts: phase transformations and carbon monoxide oxidation. Appl. Catal., A 259, 253-259 (2004).

27. Shu, Z. et al. Room-temperature catalytic removal of low-concentration $\mathrm{NO}$ over mesoporous $\mathrm{Fe}-\mathrm{Mn}$ binary oxide synthesized using a template-free approach. Appl. Catal., B 140-141, 42-50 (2013).

28. Zhao, H. et al. $\mathrm{ZnAl}_{2} \mathrm{O}_{4}$ as a novel high-surface-area ozonation catalyst: One-step green synthesis, catalytic performance and mechanism. Chem. Eng. J. 260, 623-630 (2015).

29. Bader, H. \& Hoigné, J. Determination of ozone in water by the indigo method. Water Res. 15, 449-456 (1981).

30. Nie, Y., Hu, C., Li, N., Yang, L. \& Qu, J. Inhibition of bromate formation by surface reduction in catalytic ozonation of organic pollutants over $\beta-\mathrm{FeOOH} / \mathrm{Al}_{2} \mathrm{O}_{3}$. Applied Catalysis B: Environmental 147, 287-292 (2014).

\section{Acknowledgements}

This work was supported by the National Natural Science Foundation of China (Grant Nos. 51538013, 21125731 and 51138009).

\section{Author Contributions}

Liqiang Yan conceived the idea and carried out sample fabrication and measurements; Hecheng Wu and Jishuai Bing supervised the project; Liqiang Yan and Jishuai Bing analyzed simulation data and co-wrote the paper. All authors, including Liqiang Yan, Jishuai Bing and Hecheng Wu discussed the results and commented on and revised the manuscript.

\section{Additional Information}

Supplementary information accompanies this paper at https://doi.org/10.1038/s41598-019-50910-w.

Competing Interests: The authors declare no competing interests.

Publisher's note Springer Nature remains neutral with regard to jurisdictional claims in published maps and institutional affiliations.

(c) (i) Open Access This article is licensed under a Creative Commons Attribution 4.0 International License, which permits use, sharing, adaptation, distribution and reproduction in any medium or format, as long as you give appropriate credit to the original author(s) and the source, provide a link to the Creative Commons license, and indicate if changes were made. The images or other third party material in this article are included in the article's Creative Commons license, unless indicated otherwise in a credit line to the material. If material is not included in the article's Creative Commons license and your intended use is not permitted by statutory regulation or exceeds the permitted use, you will need to obtain permission directly from the copyright holder. To view a copy of this license, visit http://creativecommons.org/licenses/by/4.0/.

(C) The Author(s) 2019 